DOI:

Cite this as:

Widiamoksa, G., et. al. The Influence of Fernald Method to Increase Early Writing Skill of Students with Intellectual Disability in Grade II of SLB Panca Bakti Mulia Surakarta 2018-2019. Indonesian Journal of Disability Studies (IJDS).2019: Vol. 6(1): PP 89-94.

\title{
The Influence of Fernald Method to Increase Early Writing Skill of Students with Intellectual Disability in Grade II of SLB Panca Bakti Mulia Surakarta 2018-2019
}

\author{
1* Garit Widiamoksa, ${ }^{2}$ Sugini, ${ }^{3}$ Mahardika Supratiwi \\ 1, 2,3 Special Education, Faculty of Teacher Training and Education Sebelas Maret University, Surakarta, 57126, \\ Indonesia
}

\begin{abstract}
This research aims to determine the influence of Fernald method to increase early writing skill of students with intellectual developmental disorder in grade II of SLB Panca Bakti Mulia Surakarta in academic year 2018/2019. This research used pre-experimental design with one group pretest-posttest design. The sample of this research is five students with intellectual developmental disorder in II grade of SLB Panca Bakti Mulia Surakarta in academic year 2018/2019, using saturation sampling technique. The research instrument uses a written test in the form of a short answer, namely a written test that thickens words, copies words, and completes words. The results of this study were analyzed using a signed ranking test (Wilcoxon Sign Rank Test). Based on the data analysis that has been done, it is known that the value of $Z_{\text {count }}=-2,060$ with Asymp. Sig. (2-tailed) of 0.039 which is below the significance level $(\mathrm{p}<0.05)$. These results indicate that the Fernald method has an effect on improving the writing skills of beginning class II students with intellectual developmental disorder at SLB Panca Bakti Mulia Surakarta Academic Year 2018/2019.
\end{abstract}

Keywords: Fernald method, students with intellectual developmental disorder, early writing skill.

\section{Introduction}

Education is a system that is intentionally designed to create individuals who have the ability, character, noble character, healthy, knowledgeable, capable, creative, independent and become a democratic and responsible citizen. Education is also a conscious effort to prepare students for the whole development of Indonesian humanity through activities of guidance, learning, and training so that students play a role in their future lives.

The mandate of the right to education for children with special needs is stated clearly in Indonesian Law No. 20 of 2003 concerning the National Education System stated that special education is an education for students with disabilities or having extraordinary intelligence held in an inclusive or special schools and through this special education children with special needs receive services and learning that can help them in community life.

Mentally retarded children are one part of children with special needs, who are also entitled to receive proper education in accordance with the developmental barriers they experience without discrimination. Children with mental retardation generally have a level of intellectual ability below the average. According to Amin (1985: 12) what is meant by intelligence is below the average is if the development of the age of intelligence (Mental Age, abbreviated MA) someone is underdeveloped or under the age of growth (Chronological Age, abbreviated CA).

Children with mental retardation who have intellectual abilities below the average, low thinking skills, attention and memory are weak, and difficult to think abstractly such as learning

\footnotetext{
* Corresponding author: Garit Widiamoksa garitwidiamoksa@gmail.com

Published online at http://IJDS.ub.ac.id/2019

Copyright @ 2019 PSLD UB Publishing. All Rights Reserved
} 
to count, reading and writing makes the learning capacity of mentally retarded children is also limited (Somantri, 2006: 105). Cognitive function or intellectual ability in children with low mental retardation causes children difficulty in receiving or mastering the learning given by the teacher in the school so often the teacher repeats the learning given. Academic ability in mastering teaching in schools is inseparable from writing skills.

Writing is one of the skills in language and taught early but because mentally retarded children experience obstacles in intelligence causing the ability to write children with mental retardation less. Tarigan (2008: 3) explained that writing is a language skill that is used to communicate indirectly, not face to face with other people. Related to language, mentally retarded children have difficulty in receiving stimuli due to limited intelligence capabilities.

Problems experienced in aspects of initial writing skills can hinder the learning process, so that the learning outcomes to be achieved cannot be maximized. A series of writing activities form the basis of children's language development, namely writing the beginning. Beginning writing is a prerequisite for children to learn according to the stages of cognitive development. This initial writing activity can be in the form of writing letters, stringing letters into words, and arranging words into sentences. Without writing skills, the learning process will not run smoothly so that it will hinder the achievement of learning goals.

Writing is an easy thing to do but less attention so students are still unable to understand the concepts that have been learned. Writing includes language skills to communicate that are indirect. Putri's research results (2013) state that mentally retarded children experience impaired writing skills such as writing sequentially, writing is not upside down, and difficulty in distinguishing letters and numbers with almost the same shape.

Field observations conducted at the SLB Panca Bakti Mulia Surakarta 2017/2018 school year researchers found the problem that mentally retarded children in class II had difficulty doing one of their basic academic abilities, namely difficulty in writing. Children can not distinguish letters that sound almost the same, and can not write the letter in question. At the time of learning the teacher only uses the learning method in the form of continuous training without interesting interlude, causing the students' initial writing skills to be low.

Based on the problems revealed above, it is necessary to have an appropriate method in teaching beginning writing skills for mentally retarded children who are adapted to the child's condition. In this study the method used was the Fernald method. The Fernald method was discovered by an expert named Grace M. Fernald and also known as the VAKT method, which is a multisensory teaching method to teach children to write, read, and spell so that children are more understanding (Abdurrahman, 2012: 217). Therefore, the VAKT method is also known as the Fernald method. In addition, there are also those who know it as a multisensory approach because the teaching involves a lot of sensory. In accordance with the opinion of Yusuf (2005: 168), a multisensory approach is based on the assumption that children will be able to learn well if the teaching material is presented in various modalities namely visual, auditory, kinesthetic (movement), and tactile (touch). The VAKT method can be developed for writing learning activities, so students will be more motivated to learn to write.

Based on the background of the problem, the researcher proposed a problem statement as follows: "Does the use of the Fernald method affect the improvement of initial writing skills in second-grade mentally retarded children at SLB Panca Bakti Mulia Surakarta in the 2018/2019 academic year ?". The purpose of this study was to determine whether or not the influence of the use of the Fernald method affected the improvement of initial writing skills in secondgrade mentally retarded children at SLB Panca Bakti Mulia Surakarta 2018/2019 school year.

\section{Research Methodology}

The research was conducted at the SLB Panca Bakti Mulia Surakarta in November 2018. The design in this study used an experimental research design with the form of one group pretest-posttest design. The research subjects were mentally retarded children at the SLB Panca Bakti Mulia Surakarta 2018/2019 school 
year, totaling 5 children. This study uses a saturated sampling technique, researchers used a saturated sampling technique because all of the population of this study were used as research samples. Sugiyono $(2014,124)$ states that Saturated sampling is a sampling technique if all members of the population are used as samples. This is done if the number of the population is relatively small, which is less than 30 people.

The data collection technique used in this study was to use a test. The type of test used to measure writing ability is a written test. The validity test technique used in this study is content validity. According to Sukardi (2003: 123) content validity is the degree to which a test measures the scope of the substance to be measured. The validity of the contents of this research instrument will be validated by experts or experts in their fields. Reliability test in this study uses interrater reliability. According to Azwar (2013: 91) argues that an instrument is reliable if the results given by the rater are consistent between one rater and the other.

Test instruments in the form of tests were tested on three validators from the fields of construction, language and material. Data analysis in this study used quantitative analysis, namely by non parametric statistical analysis techniques, Wilcoxon Sign Rank Test. This data analysis calculation uses the help of the SPSS 22 application.

\section{Results and Discussion}

Before carrying out the treatment, the researcher first carried out the pretest activity to find out the child's initial ability in writing the beginning. The pretest activity has been carried out and the test value data is obtained as follows:

Table 1. Pretest Values Statistics

\begin{tabular}{|c|c|c|}
\hline & Statistics & \\
\hline \multirow[t]{2}{*}{$\mathrm{N}$} & Valid & 5 \\
\hline & Missing & 0 \\
\hline \multicolumn{2}{|c|}{ Mean } & 51,0000 \\
\hline \multicolumn{2}{|c|}{ Median } & 40,0000 \\
\hline \multicolumn{2}{|c|}{ Mode } & 35,00 \\
\hline \multicolumn{2}{|c|}{ Std. Deviation } & 20,43282 \\
\hline \multicolumn{2}{|c|}{ Minimum } & 35,00 \\
\hline \multicolumn{2}{|c|}{ Maximum } & 80,00 \\
\hline \multicolumn{2}{|c|}{ Sum } & 255,00 \\
\hline
\end{tabular}

Cite this as:

Widiamoksa, G., et. al. T he Influence of Fernald Method to Increase Early Writing Skill of Students with Intellectual Disability in Grade II of SLB Panca Bakti Mulia Surakarta 2018-2019 Journal of Disability Studies (IJDS).2019: Vol. 6(1): PP 89-94
Based on statistical data in table 1. above, it can be seen that the initial ability of children in shopping is still low with the average value (mean) obtained is 51 , the middle value is 40 , for values that often appear 35, standard deviation is 20.43282 , the lowest value is 35 , and the highest value is 80 . The pre-test value data can be presented in the form of histograms, namely:

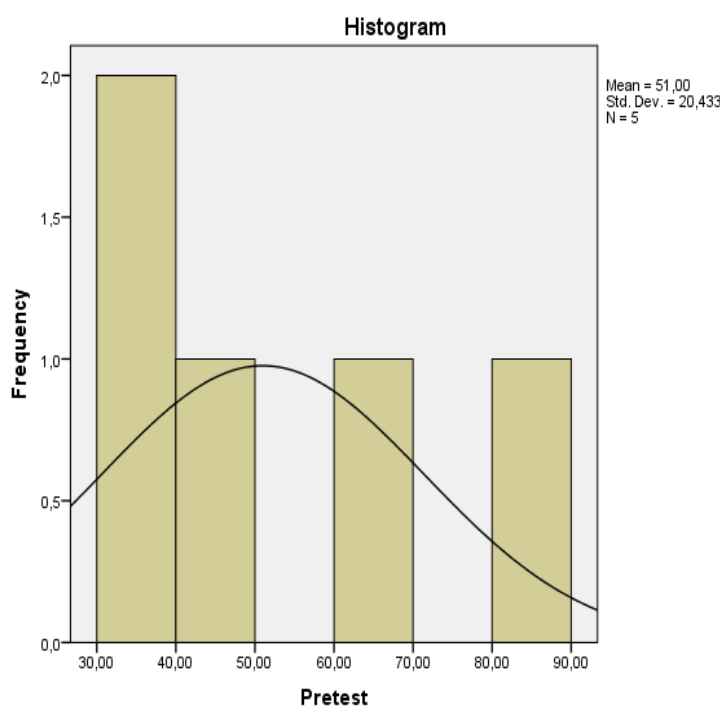

Fig 1. Pretest Values Histogram

Subjects were given treatment after the pretest using the Fernald method. The next step is post-test activities. The post-test activity aims to determine the subject's ability to write initial skills after the treatment is done by using the Fernald method. The data obtained from posttest activities are:

Table 2. Post-test Values Statistics

\begin{tabular}{|c|c|c|}
\hline Pos & Statistics & \\
\hline \multirow[t]{2}{*}{$\mathrm{N}$} & Valid & 5 \\
\hline & Missing & 0 \\
\hline \multicolumn{2}{|c|}{ Mean } & 69,0000 \\
\hline \multicolumn{2}{|c|}{ Median } & 65,0000 \\
\hline \multicolumn{2}{|c|}{ Mode } & $55,00^{\mathrm{a}}$ \\
\hline \multicolumn{2}{|c|}{ Std. Deviation } & 15,16575 \\
\hline \multicolumn{2}{|c|}{ Minimum } & 55,00 \\
\hline \multicolumn{2}{|c|}{ Maximum } & 85,00 \\
\hline \multicolumn{2}{|c|}{ Sum } & 345,00 \\
\hline
\end{tabular}

Based on statistical data in table 2. above, it shows that the average value obtained by students is 69 , with a middle value of 65 , a value 91 
that often appears 55, standard deviation 15.16575 , lowest value 55, and the highest value of 85 .

The post-test value data can be presented in the form of histograms, namely:

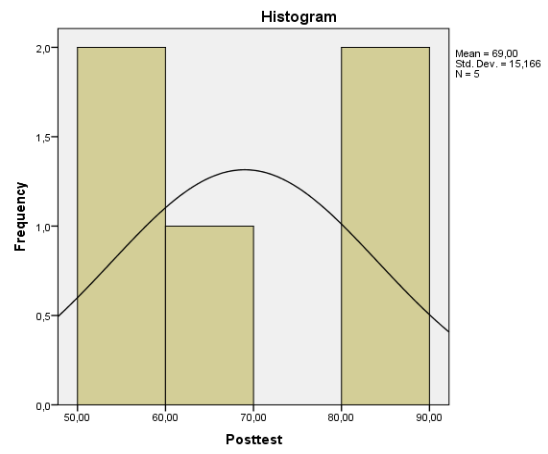

Fig 2. Post-test Values Histogram

Based on the description of the data above, the difference in the average value indicates a difference in conditions before and after treatment. It can be seen that the average value before being given treatment is 51 , while the average value after treatment using the Fernald method is 69. The difference in the average value indicates a difference in conditions before and after treatment, there is an increase in the value average pretest and posttest. The comparison data between the pretest and posttest values are as follows:

Table 3. Pretest and Posttest Values Comparison

\begin{tabular}{cccc}
\hline No. & $\begin{array}{c}\text { Student's } \\
\text { Name } \\
\text { (Initial) }\end{array}$ & Pretest & Posttest \\
\hline 1. & FA & 35 & 55 \\
2. & FDL & 65 & 85 \\
3. & HLN & 80 & 85 \\
4. & RK & 40 & 65 \\
5. & YY & 35 & 55 \\
\hline \multicolumn{2}{c}{ Mean } & 51 & 69 \\
\hline
\end{tabular}

Based on the results of table 3 . it can be seen that there is an increase in the value of the results of the pretest and posttest. The increase in value that occurs in the average results of the pretest and post-test is from 51 to 69 . The following are the values of the pretest and posttest in the form of histograms:

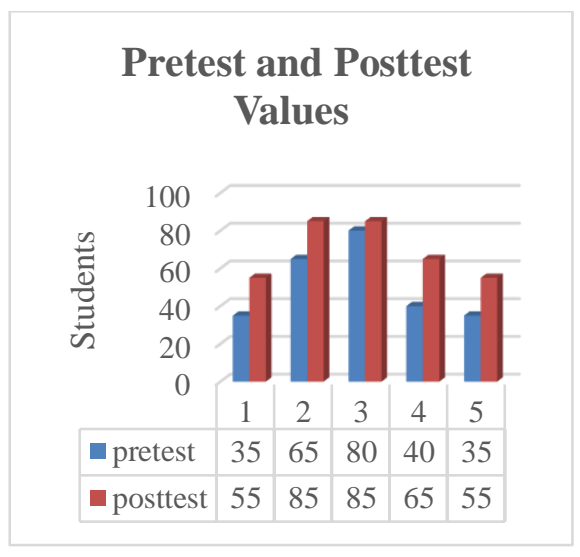

Fig 3. Pretest and Posttest Values Histogram

Next is the statistical test results data from the Wilcoxon Sign Rank Test analysis using the SPSS 22 application. The results are as follows:

Table 4. Statistical Test Data

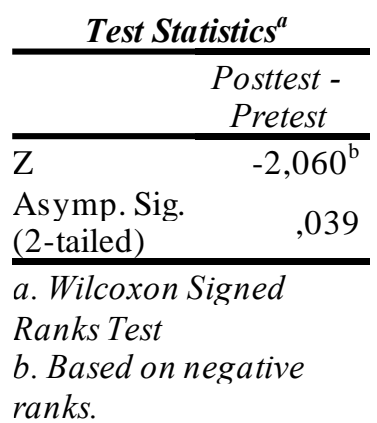

Based on table 4. the above can be obtained asympt. Sig analysis (2-tailed) $=0.039$ $<0.05$, in the data Asymp. Sig is less than the significance level of 0.05 , so $\mathrm{H}_{\mathrm{a}}$ is accepted and $\mathrm{H}_{\mathrm{o}}$ is rejected. Based on these statistical results it can be concluded that the use of Fernald's method significantly influences the improvement of initial writing skills for secondgrade mentally retarded students at the SLB Panca Bakti Mulia Surakarta 2018/2019 academic year is acceptable.

The level of intelligence of children with low mental retardation makes children experience difficulties in following the learning process. Like the opinion expressed by Somantri 
(2006: 105) which states that mentally retarded children have limited intellectual function so that it affects the ability to learn and obtain information through reading and writing. Mentally retarded children who have intellectual abilities below average, low thinking skills, weak attention and memory, and difficult abstract thinking such as learning to count, reading and writing make the learning capacity of mentally retarded children limited. Cognitive or intellectual function in mentally retarded children low causes children to experience obstacles in receiving or mastering the learning given by the teacher at school. Learning barriers experienced by mentally retarded children have an impact on the low writing skills of children.

According to Caroll (in Angkowo \& Kosasih, 2007: 51), that student learning outcomes are influenced by five factors namely (1) learning talent, (2) time available for learning, (3) individual abilities, (4) quality of teaching, ( 5) environment. Clark (in Sudjana \& Rivai, 2001: 39) reveals that student learning outcomes in schools are $70 \%$ influenced by students' abilities and $30 \%$ are influenced by the environment.

Viewed from the obstacles experienced by mentally retarded children, the use of the Fernald Method or VAKT is one of the learning methods that can be applied to mentally retarded children to overcome these problems. Like the opinion expressed by Yusuf (2005) which states that with low memory ability the use of the sense of hearing, vision, touch, will help the child easily remember the learning being taught. Maulana (2013) revealed that VAKT is a method with a multisensory approach because in its implementation it uses a lot of sensory such as vision, hearing, taste and touch and other senses so that children can live it with confidence. The VAKT method can be developed to write learning activities, so students will be more motivated to learn to write. Maulana (2013) suggested that the effective VAKT method was used to improve initial writing skills

The results of the Kumilasari (2016) study conducted at the Sawahlunto SLB Talawi aimed to find out whether the initial writing skills (vowels) for mentally retarded children could increase through the VAKT method showed that the writing ability of vowel starts $(\mathrm{a}, \mathrm{i}, \mathrm{u}, \mathrm{e}, \mathrm{o})$ through the VAKT method for mentally retarded children is increasing through the VAKT method and there is an increase in the child's vocabulary. From these various opinions it can be concluded that the Fernald or VAKT method can be used to teach early writing skills for mentally retarded children because in this study, the Fernald method process can provide children's understanding of letters and words using sensory modalities that children like.

Based on the discussion and results of research on the Fernald method described above, it can be said that the use of the Fernald method for mentally retarded children is proven to provide convenience in learning the material given by the teacher during the learning process. Thus the Fernald method is proven to have a significant influence between before and after treatment. So it can be concluded that the use of the Fernald method influences the improvement of writing skills in the beginning of the second grade mental retardation students of SLB Panca Bakti Mulia Surakarta in the 2018/2019 school year.

\section{Conclusion}

Based on the results of the study, it can be concluded that the use of the Fernald method influences the improvement of initial writing skills for class II mentally retarded children at the SLB Panca Bakti Mulia Surakarta 2018/2019 school year.

\section{Suggestion}

Based on the conclusions and implications of the results of this study, the researcher gave suggestions as material for consideration as follows:

\section{For The Teacher}

The teacher can use and develop Fernald's own method to improve the success of writing skills in the beginning of mentally retarded students.

\section{For Student}

Students are expected to practice diligently to practice their skills in writing using the Fernald method, so that the writing skills of the students' progress increases.

\section{For Other Researchers}


Other researchers who will conduct research using the Fernald method should be able to modify the method so that more material related to writing starts and can be applied to mentally retarded children or other special needs children in different schools.

\section{References}

Abdurrahman, M. (2012). Anak Berkesulitan Belajar: Teori, Diagnosis, dan Remediasinya. Jakarta: PT Rineka Cipta.

Amin, M. (1995). Ortopedagogik Anak Tunagrahita. Bandung: Departemen Pendidikan dan Kebudayaan Direktorat Jendral Pendidikan Tinggi.

Angkowo, R., dan Kosasih, A. (2007). Optimalisasi Media Pembelajaran.Jakarta: PT.Grasindo.

Azwar, Saifuddin. (2013). Metode Penelitian. Yogyakarta: Pustaka Pelajar.

Kumilasari, Desi. (2016). Meningkatkan Kemampuan Menulis Huruf Vokal (a, i, u, e, o) Melalui Metode VAKT bagi Anak Tunagrahita Sedang di SLB Talawi Sawahlunto. Jurnal Ilmiah Pendidikan Khusus, 5 (2). (Online), (http://ejournal.unp.ac.id/index.php.jupekhu ), Accessed 11 December 2018.
Maulana, Syafrina. Dkk. (2013). Efektifitas Metode Vakt Untuk Meningkatkan Kemampuan Menulis Permulaan Bagi Anak Kesulitan Belajar. Jurnal Ilmiah Pendidikan Khusus, 2 (3). (Online), (http://ejournal.unp.ac.id/index.php.jupekhu), Accessed 11 December 2018

Putri, Ni Luh. (2013). Kesulitan Menulis Permulaan Pada Anak Usia Dini dengan Kelainan Tunagrahita Ringan. Jurnal Ilmu Pendidikan, 1(19). Taken from: http://journal.um.ac.id/index.php/jip/article/vie w/3760

Somantri, S. (2006). Psikologi Anak Luar Biasa. Bandung: PT. Refika Aditama.

Sugiyono. (2014). Metode Penelitian Pendidikan Pendekatan Kuantitatif, Kualitatif, dan R\&D. Bandung: CV. Alfabeta.

Sukardi. (2003). Metodologi Penelitian Pendidikan. Jakarta: PT Bumi Aksara.

Tarigan, H.R. (2008). Menulis Sebagai Suatu Keterampilan Berbahasa. Bandung: FKKSK FKIP.

Yusuf, Munawir. (2005). Pendidikan bagi Anak dengan Problem Belajar. Jakarta: Depdiknas. 